\title{
Finite land resources and competition
}

Haberl, Helmut ; Mbow, Cheikh; Deng, Xiangzheng ; Irwin, Elena G; Kerr, Suzi ; Kuemmerle, Tobias; Mertz, Ole; Meyfroidt, Patrick; Turner II, B. L.

Published in:

Rethinking Global Land Use in an Urban Era

Publication date:

2014

Document version

Early version, also known as pre-print

Citation for published version (APA):

Haberl, H., Mbow, C., Deng, X., Irwin, E. G., Kerr, S., Kuemmerle, T., Mertz, O., Meyfroidt, P., \& Turner II, B. L. (2014). Finite land resources and competition. In K. S. Seto, \& A. Reenberg (Eds.), Rethinking Global Land Use in an Urban Era (pp. 35-69). MIT Press. Strungmann Forum reports Vol. 14

http://mitpress.mit.edu/books/rethinking-global-land-use-urban-era 


\title{
4
}

\section{Finite Land Resources and Competition}

\author{
Helmut Haberl, Cheikh Mbow, \\ Xiangzheng Deng, Elena G. Irwin, Suzi Kerr, \\ Tobias Kuemmerle, Ole Mertz, \\ Patrick Meyfroidt, and B. L. Turner II
}

\begin{abstract}
Rising demand for land-based products (food, feed, fiber, and bioenergy) as well as conservation of forests and carbon sinks create increasing competition for land. Landuse competition has many drivers, takes different forms, and can have many significant implications for ecosystems as well as societal well-being. This chapter discusses several emerging issues, including the effect of increased demand for nonprovisioning ecosystem services (biodiversity conservation and carbon sequestration), urbanization, bioenergy, and teleconnections. Three major types of land-use competition are discerned: production versus production (e.g., food vs. fuel), production versus conservation (e.g., food production vs. conservation), and built-up environment versus production or conservation (e.g., food vs. urban). Sustainability impacts that result from land-use competition are analyzed and found to differ strongly between the different types of land-use competition. They are associated with important trade-offs and high uncertainty. Institutional aspects related to land-use competition are discussed using a conceptual model that distinguishes types of institutions (government, private, community) as well as their functions (objectives, distribution/equity, effectiveness/ efficiency). Analysis of long-term trajectories suggests that land-use competition is likely to intensify in the medium- to long-term future, mainly in the face of expected scarcities in resource supply (e.g., in terms of limited resources such as fossil fuels), mitigation and adaptation policies related to climate change, as well as climate change impacts and demographic pressures. The chapter concludes with a discussion of major research gaps, and it outlines priority research topics, including the improved analysis of interdependencies of land and energy systems, "land architecture" (i.e., the significance of spatial configurations), and multiscale models to assess local-global connections and impacts.
\end{abstract}




\section{Introduction}

Competition for land is emerging as a globally pressing issue due to the sheer scale of global demand for land-based products and critical changes in processes of society-nature interaction that affect land use. The potential magnitude of the changes to the land surface of Earth that result from this increased competition is large, and land-use competition can have major implications for ecosystems and societal well-being (Coelho et al. 2012; Smith et al. 2010). In some cases, increased competition is due to new sources of demand (e.g., nascent markets for ecosystem services that have arisen from increased global demand for biodiversity conservation, climate change mitigation, and other services) whereas in others, long-standing forms of land-use competition reach threshold levels due to changes in environmental processes (e.g., climate change) that have intensified the biophysical and human impacts of land competition (Andersen et al. 2009). Indeed, Lambin and Meyfroidt (2011) suggest that society may face a looming global scarcity of productive lands over the coming decades. Land-use competition is a systemic phenomenon characterized by complex feedback processes between human and biophysical components in the land system (Figure 4.1).

Limits to land-based production, beyond those set by net primary production (Vitousek et al. 1986), and the losses in ecosystem services which a land system can withstand, are set by ambient environmental conditions of the land and the technomanagerial system employed on it, both of which vary considerably. For example, until recently the Chaco region of Argentina was not considered ideal for cultivation; however, drought-tolerant soybean strains have made it so (Zak et al. 2008). Perhaps even more difficult is the complexity of decision factors that determine which land-use system is employed. Consistent

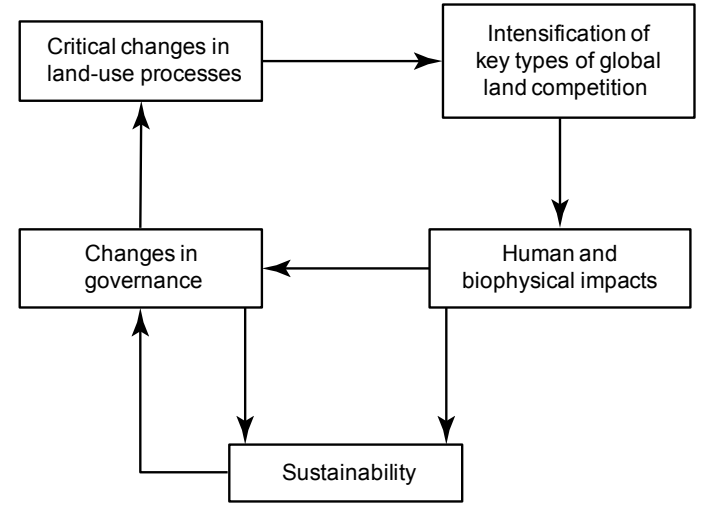

Figure 4.1 Conceptualization of the complex feedback processes involved in landuse competition. Competition for land both results from and affects a host of other factors such as governance, land-use change, sustainability as well as human and biophysical impacts. 
with the proposition that intensive agriculture spares other lands from cultivation (Balmford et al. 2005; Phalan et al. 2011), mechanized commercial cultivation based on synthetic fertilizers and pesticides in the developed world has outpaced consumption, thereby allowing substantial contraction of agricultural land without substantially increasing net imports from abroad (Krausmann et al. 2012). In developing economies, by contrast, there is little evidence that agricultural intensification takes marginal lands out of cultivation or reduces the clearing of new lands (Rudel et al. 2009b). Indeed, intensification may result in a rebound effect which increases the total demand for land and production, as it makes farmers more competitive, or in a rise in consumption of products with elastic demand (Lambin and Meyfroidt 2011).

Whether or not land limits are being reached, the potential magnitude of the changes in Earth's land surface that result from the increased land competition is large and carries significant trade-offs for human-environment well-being. Understanding the trajectory of competition-driven changes requires a better understanding of the sociopolitical and economic dimensions of the problem (Coelho et al. 2012; Smith et al. 2010), while understanding the trade-offs and their implications demands improved data and new analyses to address the potential extent, pattern, and magnitude of the various forms of land competition (Turner et al. 2013).

We define land-use competition as a contest between different purposes, or functions, for which a given piece of land, or the resources flowing to and from such land, could be used. This competition involves the outcomes of land cover and services provided by land use (e.g., forest for carbon storage vs. opening land for agriculture) as well as the use of the products produced on the land (e.g., maize for food vs. maize for feed vs. maize for biofuel). This perspective goes beyond typical land-use change studies, as the main analytical entry point is the competition and inherent trade-offs between several (two or more) land uses. Land-use competition may involve the character of the land unit itself, as in the case of agriculture competing with protected areas. Alternatively, the competition can be disconnected from the land itself and occur further along the supply chain, as in the case of crops that can be sold for food, biofuels, or fodder. Some types of land-use competition involve different actors competing for the land, whereas others involve the same actor switching between several possible uses.

In this chapter, we identify critical forms of land-use competition that are currently underway, the ways in which competition takes place, the trade-offs it generates, and its implications for sustainability. We identify specific landcompetition trends and link these to the types of land competition that are emerging or expected to emerge globally. We discuss impacts of major types of land-use competition across human and biophysical dimensions, in particular with respect to their implications for sustainability, and consider the role of institutions and examine how intended outcomes compare to the actual impacts and implications of unintended outcomes for potential changes to governance. 
Finally, we discuss long-term biophysical and human trends and how they may potentially affect changes in global land-use competition on the medium to long term.

We conclude that land-use competition is a major phenomenon driving land-use change. Although there are few types of land-use competition that are entirely new, the sheer scale of ongoing changes is likely to result in substantial challenges on short-, medium-, and probably long-term timescales. Major categories include land demand for conservation (biodiversity, carbon storage), bioenergy, and livestock feed (grazing and fodder crops). We identify important research gaps that are needed to work toward more sustainable future land-use systems and cope with the intertwined challenges of biodiversity loss, climate change, as well as food and energy supply.

\section{Trends in Land-Use Competition}

There are few, if any, major types of land competition underway that are entirely new. Land set aside for conservation, urban impacts on hinterlands, woodfuel forest land, and long-distant transport of food_-versions of the categories of trends we discuss below-have a long history. Those which we single out below, however, have entered a new stage of significance and thus constitute trends in competition that warrant attention.

\section{Ecosystems and Biodiversity Conservation As a Land Use}

Historically, land change has primarily taken place to increase the production of goods or resources, provide ecosystem services (e.g., agriculture and forestry), and meet urban and infrastructure needs, including recreation and waste deposition (Dunlap and Catton 2002). Protected areas, in contrast, tend to be established on the remaining marginal lands, usually at a distance from "productive" lands (Joppa and Pfaff 2009). Major initiatives are currently underway to set aside land for nonprovisioning ecosystem services (regulatory, supporting, and cultural; MEA 2005) and biodiversity. This change involves:

- $\quad$ protected area networks (Batisse 1982; Soares-Filho et al. 2010) such as the Meso-American Biological Corridor,

- carbon offsets and payments for ecosystem services (PES) initiatives such as Reducing Emissions from Deforestation and Forest Degradation (REDD+) (Angelsen 2009), or

- land-use restrictions to protect watersheds in various ways (Pires 2005).

Increasingly, private NGO trust initiatives are acquiring land for conservation purposes, thus affecting future development which could otherwise take place on it (Kull et al. 2007; Langholz and Lassoie 2001). Conservation is 
increasingly being driven by the official recognition of indigenous lands and reserves (Ricketts et al. 2010), as is the "rewilding" of land-a practice that often occurs in communities which have lost agriculture or forestry activities in which the rewilding stimulates outdoor tourism.

Potential or actual agricultural land competes with demands for nonprovisioning ecosystem services and the conservation of natural ecosystems and biodiversity. Although rural land managers have long been aware of the importance of most ecosystem services, demand for nonprovisioning ecosystem services has become significant in spatial amplitude and intensity as well as in penetration into markets and cultural/institutional spheres (see Table 13.1 in Gentry et al., this volume). Land conservation and restoration must now be considered a new form of land use - one that actively competes with others - rather than a passive "victim" of land-use competition or residual category of land.

\section{Urbanization}

We are entering a world in which the large majority of humankind lives in urban areas. The most recent projections by the United Nations estimate a global population of 9.3 billion by 2050, with an estimated 6.3 billion living in urban areas, nearly one-third of which will reside in the cities of China and India. Most of this population growth will occur in small- and medium-sized cities, not in mega-cities (Seto et al. 2011). Globally, urban land area is expected to triple in the time period from 2000 to 2030 (Seto et al. 2012b). In the developing world, urbanization involves a significant increase in the expected material standard of living which, in turn, will increase demand of land-based products. In the developed world, urban living can trigger significant economies of scale in efficiency of resource use when it results in increased population density. In the developing world, however, rural to urban migration tends to increase expectation for consumption, resulting in an increased demand for resources. Increased "urbanity," defined by urban livelihoods and lifestyles (see Boone et al., this volume), occurs in peri-urban and rural areas as the result of ecosystem amenities that attract "footloose" (i.e., nonpermanent or transient) households and firms away from traditional urban areas to places with mountains, coastlines, and other high-valued natural amenities (Deller et al. 2001; McGranahan 2008; Carruthers and Vias 2005). Regardless of where it occurs, this massive urban growth creates demands on rural and often distal populations to provide land-based resources and is a strong force behind contemporary telecouplings (see Eakin et al., this volume). An immediate land competition that results from this growth is the capacity of urban land uses to outbid peri-urban and rural land uses, pushing agriculture elsewhere (Seto et al. 2002). Indirect competition follows from the restructuring of the urban hinterlands owing to the demands from the city (Seto et al. 2012b). 


\section{Nonfossil Land-Based Energy Provision}

Bioenergy use is expected to rise substantially by 2050 and might require approximately as much biomass as is currently harvested for food, feed, and fiber (Chum et al. 2012; GEA 2012; Krausmann et al. 2008). Burning biomass is an ancient means of generating energy, but the sheer scale at which this resource might be used in the future is unprecedented. New, and with profound current or future impacts on land systems, is the use of land to grow energy crops such as sugarcane, maize, switch grass, and oil palm, although many of these crops are still mainly, or at least partly, used for nonfuel purposes. Future bioenergy demand will further contribute to oil palm transforming tree cover in parts of southeastern Asia; sugarcane is commanding large tracts of land in Brazil; and a significant portion of the corn crop in the United States has already been allocated to fuel so that food maize prices have risen substantially on the international market (Chum et al. 2012; McNew and Griffith 2005). Furthermore, lands are also increasingly allocated for water power as well as wind and solar farms, yet with much smaller impacts on the land surface than with bioenergy (Coelho et al. 2012). If global reliance on fossil fuels and nuclear power continues to decline, lands devoted to these types of energy sources can be expected to continue to increase globally.

\section{Teleconnections}

Global-scale land changes and teleconnections (i.e., an exogeneous driver acting on a distant system, such as long-distant transport of land-based products) have a long history (Crosby 1986; Turner and Butzer 1992). However, as the separation of land production from resource consumption grows larger (Erb et al. 2009) and the speed by which social processes operate increases (Foley et al. 2011), a case can be made that the scale of current socioeconomic teleconnections is unprecedented. This is exemplified by the Chaco soybean example discussed above and illustrates Harvey's space-time compression concept (Harvey 1990). For example, subsidized maize ethanol production in the U.S. Midwest has decreased soybean production there, which in turn has led to the expansion of soybean crops in the Chaco region to meet the demand of fodder for Asia's boom in meat consumption (Macedo et al. 2012; Morton et al. 2006). In yet another example, forest transitions documented for various regions across the world appear to be related to the transfer of production elsewhere (Meyfroidt et al. 2010; Meyfroidt and Lambin 2011). In addition, informational feedbacks between cities and their hinterlands are creating socioecological systems that are "teleconnected" over increasing distances (Seto et al. 2012b; Eakin et al., this volume). Also new are biophysical teleconnections driven by anthropogenic global environmental change, which affect the suitability of land for different uses (Pielke et al. 2002). As an example, tropical deforestation affects global climate, changing temperature and precipitation 
for rainfed and irrigation farming everywhere. Farming is expected to be pushed poleward (Olesen and Bindi 2002), while snowpack-fed waters for irrigation in the U.S. Southwest are expected to decline (MacDonald 2010).

\section{Summary}

The emergence of these trends in land competition is associated with general trends in the characteristics of land users and the land systems they produce (Figure 4.2). Worldwide the proportion of land used by large, capital-intensive agri-businesses producing for distal markets has risen relative to small, laborintensive family farms responding to more proximate demands (McCullough et al. 2008). This shift is often accompanied by a transition from heterogeneous, multifunctional landscapes providing not only goods but also nonprovisioning ecosystem services, toward homogeneous, monofunctional landscapes where many nonprovisioning ecosystem services deteriorate (Clough et al. 2011; Perfecto and Vandermeer 2010; Tscharntke et al. 2012). Land-use transitions need not involve moving along all these axes at the same time, and trends may go in opposite directions depending on the places or actors involved. Yet, in areas where land-use competition is rife, the changes shown in Figure 4.2 often bundle together.

These and other changes in land use that result from land competition are largely related to the neoliberalization of the global economy and, increasingly, to the rise in importance of ecosystem and landscape preservation (see Gentry et al., this volume). Economic instruments are increasingly used to regulate land production and environmental governance: witness the spread of carbon markets (e.g., Angelsen 2008), water quantity (Grafton 2011) and quality markets (Shortle and Horan 2008), and PES schemes (Kinzig et al. 2011). These

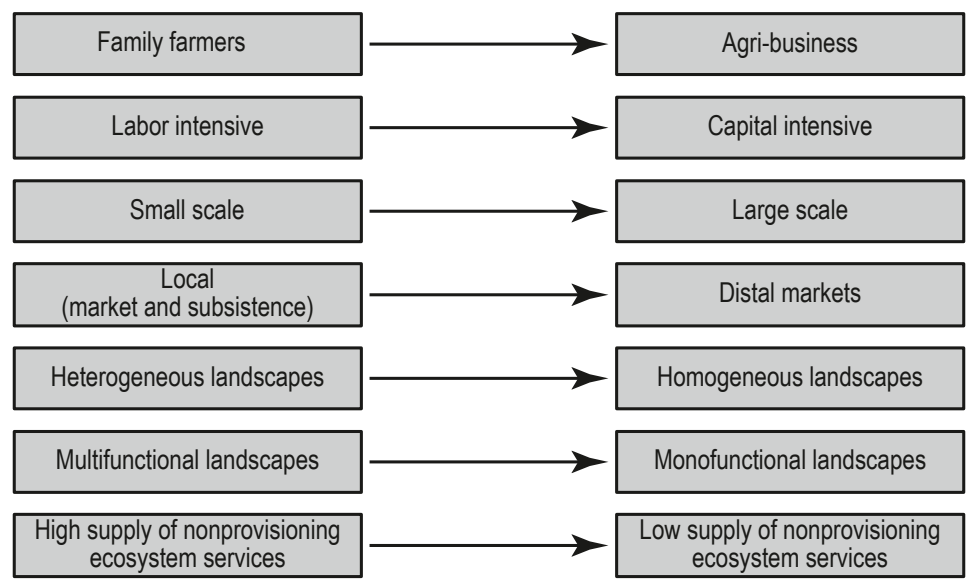

Figure 4.2 Dominant trends in structural changes in agricultural and forestry systems. 
market mechanisms in tandem with urbanization, in turn, affect local cultures, knowledge systems, and land-use practices.

\section{Global Land-Use Competition: Major Categories}

Land use can be broadly characterized as involving conservation, production, and the built environment:

- Conservation: the maintenance of land for nonprovisioning ecosystem services. Important services are biodiversity, carbon sequestration and storage, watershed protection, erosion control, detoxification and purification in soils, pollination, pest control, etc. As detailed above, maintenance of cultural ecosystem services (among others as part of indigenous cultures) or of environmental amenities are also increasingly important forms of this land use.

- Production: the use of the land for production or most provisioning services, essentially agriculture and forestry. Important production types are timber extraction, nonfood tree crops, annual and perennial food crops, and nonfood annual crops for feed, biofuel, clothing, water yield, among others.

- Built environment: the construction of settlements (cities to villages), impervious surface infrastructure such as roads, waste deposits as well as large dams and surface mining. These changes in land cover are either irreversible or require large investments to be reversed.

Land-use competition involves (a) production versus production, as in the case of land being used for either food or biofuel production; (b) production versus conservation (e.g., when forests are protected to preserve carbon stocks and prevent agricultural expansion); and (c) built environment versus conservation or production. Within these categories, we identify forms of land competition that appear to be especially significant in regard to its global reach or significance for large regions, its escalating pace of change, and its large social and environmental significance (Tables 4.1 and 4.3; see also Figure 1.1 in Seto and Reenberg, this volume).

\section{Local Food or Feed versus Food for Distant Markets}

The conversion of food production for local consumption or local markets to food production for distant markets has been occurring for centuries, but current escalating competition in much of the Global South is affecting a wide range of production systems and crops. This competition has intensified as a result of international demand for commerical products and opportunities to engage the appropriate markets, often through state- or NGO-led agents or private middlemen. Two specific categories are the change to commercial 
production of feed and biofuel, which are discussed separately below. In some instances, such as in Brazil, cascading changes in land use are involved (e.g., sugarcane pushes soybeans to other lands which, in turn, pushes pasture into tropical forest lands; Lapola et al. 2010).

\section{Traditional Multifunctional Agriculture versus Agri-business Agriculture}

This competition typically involves change from highly diverse land-use systems, often integrated agriculture and forestry with high levels of nonprovisioning ecosystem services, to monoculture-like cropping with little, if any, integration of forestry and low levels of nonprovisioning ecosystem services (Carlson et al. 2013; Ziegler et al. 2009). Agri-businesses and foreign country agencies are important actors; some of these changes may be part of the "land grabbing" phenomenon. Reduced landscape diversity, a breakup of previously closed nutrient cycles, large-scale inputs of fertilizers, pesticides, and mechanization typically follows (Krausmann et al. 2003).

\section{Food versus Feed}

Increasing global demand for animal products - especially beef - has gradually caused over the past decades a shift from human food to livestock feed production. This trend is being amplified by the surging demand of animal products as a result of rising household incomes, especially in Asia and other parts of the Global South (FAO 2008). The production of feed is escalating in many parts of the world, incuding sub-Saharan Africa and Latin America (Havlík et al. 2013). The main actors involved are large agri-businesses and companies trading in commodity markets as well as farmers responding to markets.

\section{Food or Feed versus Bioenergy}

This land-use competition is driven by the global search for solutions to mitigate climate change, which is driven by expected increases in fossil fuel prices and explicit policies that mandate or encourage biofuel production and consumption. The term "bioenergy" refers to any kind of biogenic source of technical energy and includes solid, liquid, and gaseous energy carriers. The food/feed versus bioenergy competition can take many forms, ranging from competition for feedstocks (maize for ethanol vs. maize for food or feed) to competition for land and water. In the United States and Brazil, this competition is spreading rapidly. However, cultivation of energy crops does not always compete with food production; they may even help to restore degraded lands (e.g., in salinized Australian drylands; Harper et al. 2009). Various actors are involved, ranging from smallholders that produce for new lucrative markets to large-scale agri-businesses. Large transnational energy companies are also 
Table 4.1 Major ongoing forms of land competition and their geographical location; arrows indicate the flow from the former land use/system toward the land use/system that is replacing it. Note: "geographic location" indicates areas where this type of land use competition is prominent.

\begin{tabular}{|c|c|c|c|}
\hline $\begin{array}{l}\text { Types of } \\
\text { land-use } \\
\text { competition }\end{array}$ & $\begin{array}{l}\text { Shifts in land- } \\
\text { use/system } \\
\text { characteristics }\end{array}$ & $\begin{array}{l}\text { Geographic } \\
\text { location }\end{array}$ & Examples of competition \\
\hline \multirow{4}{*}{$\begin{array}{l}\text { Production } \\
\text { vs. } \\
\text { production }\end{array}$} & $\begin{array}{l}\text { Local food or feed } \\
\downarrow \\
\text { Food for distant } \\
\text { markets }\end{array}$ & Global South & $\begin{array}{l}\text { In Senegal, groundnuts or sesame pro- } \\
\text { duced for local markets are now shifted } \\
\text { toward the global market. } \\
\text { In Vietnam, smallholders grow coffee for } \\
\text { export instead of rice for local markets. }\end{array}$ \\
\hline & $\begin{array}{c}\text { Traditional } \\
\text { multifunctional } \\
\quad \text { farm } \\
\downarrow \\
\text { Agri-business }\end{array}$ & $\begin{array}{l}\text { Global } \\
\text { especially } \\
\text { the } \\
\text { Global } \\
\text { South }\end{array}$ & $\begin{array}{l}\text { In Laos, rubber plantations are taking } \\
\text { over swidden mosaics. } \\
\text { In Indonesia and Malaysia, oil palm } \\
\text { estates replace smallholder swidden mo- } \\
\text { saics of fields, fallows, and agroforests. } \\
\text { In Ghana and Cote d'Ivoire, cocoa and } \\
\text { coffee are competing with food crops. }\end{array}$ \\
\hline & $\begin{array}{c}\text { Food } \\
\downarrow \\
\text { Feed }\end{array}$ & Global & $\begin{array}{l}\text { Newly cleared croplands in Brazil and } \\
\text { Argentina are used for soybean for animal } \\
\text { feed rather than food production. } \\
\text { In Vietnam, smallholders formerly grow- } \\
\text { ing maize for human consumption now } \\
\text { grow maize as animal feed for China. }\end{array}$ \\
\hline & $\begin{array}{c}\text { Food or feed } \\
\downarrow \\
\text { Bioenergy }\end{array}$ & Global & $\begin{array}{l}\text { Maize in the United States and Europe, } \\
\text { sugarcane in Brazil is increasingly used } \\
\text { for biofuels. In Europe, sunflower and } \\
\text { canola for bioenergy replace other crops. }\end{array}$ \\
\hline \multirow{3}{*}{$\begin{array}{l}\text { Production } \\
\text { vs. } \\
\text { conservation }\end{array}$} & $\begin{array}{c}\text { Food or feed } \\
\qquad \\
\text { Conservation }\end{array}$ & $\begin{array}{l}\text { Global } \\
\text { South, es- } \\
\text { pecially the } \\
\text { Tropics }\end{array}$ & $\begin{array}{l}\text { Reconstruction of some wildlife cor- } \\
\text { ridors in Latin America, protected areas } \\
\text { in Africa, REDD+ in many developing } \\
\text { countries are now actively restricting } \\
\text { cropland expansion, or reclaiming agri- } \\
\text { cultural areas. } \\
\text { Recultivation of abandoned lands in the } \\
\text { former Soviet Union goes in the opposite } \\
\text { direction. }\end{array}$ \\
\hline & $\begin{array}{c}\text { Conservation } \\
\downarrow \\
\text { Timber extraction }\end{array}$ & $\begin{array}{l}\text { Global, } \\
\text { especially the } \\
\text { Tropics and } \\
\text { the boreal }\end{array}$ & $\begin{array}{l}\text { Logging in remaining forest frontiers } \\
\text { (e.g., in Papua New Guinea, Laos, Su- } \\
\text { rinam, British Columbia, Siberia, or the } \\
\text { Pacific Northwest) are leading to biodi- } \\
\text { versity loss and forest degradation. }\end{array}$ \\
\hline & $\begin{array}{l}\text { Conservation } \\
\qquad \downarrow \\
\text { Tree plantations } \\
\text { for timber }\end{array}$ & Global & $\begin{array}{l}\text { Forest plantations in China, Vietnam, } \\
\text { Brazil, Chile, or Ecuador are being } \\
\text { promoted to meet timber demand, and } \\
\text { expand partly on natural forests or } \\
\text { grasslands. }\end{array}$ \\
\hline
\end{tabular}


Table 4.1 continued

\begin{tabular}{|c|c|c|c|}
\hline $\begin{array}{l}\text { Types of } \\
\text { land-use } \\
\text { competition }\end{array}$ & $\begin{array}{l}\text { Shifts in land- } \\
\text { use/system } \\
\text { characteristics }\end{array}$ & $\begin{array}{c}\text { Geographic } \\
\text { location }\end{array}$ & Examples of competition \\
\hline \multirow{2}{*}{$\begin{array}{l}\text { Built-up } \\
\text { environment } \\
\quad \text { vs. } \\
\text { production or } \\
\text { conservation }\end{array}$} & $\begin{array}{l}\text { Food or feed } \\
\qquad \downarrow \\
\text { Urban areas }\end{array}$ & $\begin{array}{l}\text { Global in } \\
\text { reach, but } \\
\text { localized } \\
\text { impact }\end{array}$ & $\begin{array}{l}\text { Cities, urban development, and increasing } \\
\text { "urbanity" globally often occurs in prime } \\
\text { agricultural locations (e.g., prime rice } \\
\text { lands in the Pearl River Delta, China). }\end{array}$ \\
\hline & $\begin{array}{c}\text { Food or feed or } \\
\text { conservation } \\
\downarrow \\
\text { Mining }\end{array}$ & $\begin{array}{l}\text { Global in } \\
\text { reach, but } \\
\text { localized } \\
\text { impact }\end{array}$ & $\begin{array}{l}\text { Mining is contributing to deforestation in } \\
\text { Cameroon, Sierra Leone, and Ghana. } \\
\text { Impacts of oil spills in the Niger Delta is } \\
\text { compromising the quality and diversity of } \\
\text { mangrove ecosystems. }\end{array}$ \\
\hline
\end{tabular}

important actors, as they are diverting a part (albeit small) of their business from fossil energy to bioenergy. Other actors include national governments and international environmental policy makers that favor the transition from fossil energy to bioenergy.

\section{Food or Feed versus Conservation}

Increasingly, land is being valued for its nonprovisioning ecosystem services and maintenance of biotic diversity, resulting in efforts to conserve "wild lands" from development. Strong policies for preserving natural habitats are increasing, from biopshere reserves and corridors to individual or community old-growth forest patches maintained as part of REDD+ (Kinzig et al. 2011). The primary actors involved are the international environmental policy makers, conservation-oriented NGOs, private actors, and national governments, the latter not only having conservation objectives, but also seeking financial compensation.

\section{Conservation versus Timber Extraction}

High-value timber is becoming increasingly scarce as many natural forests have been either replaced by secondary forests (in much of the Western world) or logged for valuable timber (in much of the Tropics, where peak timber may be in sight for some regions such as Southeast Asia; Shearman et al. 2012). Demand for this timber remains high, leading to pressures on logging conservation lands. The main actors are logging companies and urban-based industries and buyers who use the timber for a wide range of purposes. 


\section{Conservation versus Tree Plantations for Timber}

Tree plantations are rapidly expanding, mainly in Asia, subtropical and temperate South America, and peri-urban regions of the Global South due to demand for paper pulp and other wood-based products. The main actors are national governments who see the dual objective of promoting business and increasing forest cover with tree plantations and forest-based industries. These actors generally claim that forest plantations preferentially expand onto former agricultural areas, which are more accessible, have better infrastructure and labor force, and more suitable biophysical conditions such as gentle slopes (Sedjo and Botkin 1997). Yet, the evidence for that claim is mixed, confirmed for Europe and North America, where tree plantations constitute an economically viable activity for abandoned agricultural lands. But in tropical regions, the available evidence suggests that tree plantations often compete for space with natural forests and grasslands (Gerber 2011).

\section{Food or Feed versus Urbanization}

While relatively small in spatial scale, the replacement of prime agricultural land through urbanization is significant in many places (Seto et al. 2011, 2012b). Moreover, the indirect land effects of urbanization are considerable, as it alters land competition elsewhere to meet market demand. Typically, suburbanization uses up the largest tracts of former agricultural (and often highly productive) land. Urban-commercial land rents are too high for agriculture to compete. This urban deconcentration has led to a blurring between urban versus rural in many parts of North America and Europe; increasingly, places that appear "rural" based on their location and landscape form are nonetheless "urban" in their higher-order economic functioning and composition (Irwin et al. 2009). Key actors include footloose households and firms who can choose their location and policy makers who intentionally or unintentionally seek to concentrate or disperse urban growth.

\section{Food or Feed Production or Conservation versus Surface Mining}

Like urbanization, the competition of land for surface mining has a small spatial extent when viewed globally, but it constitutes an important land competition in several regions: gold mining in Western Africa or Western Amazonia, copper mining in Indonesia (Potapov et al. 2012). Surface mining for metals or rare earth minerals typically replaces forests or areas of highly productive agriculture and engender substantial spillover effects on neighboring areas, such as water and soil pollution (Hilson 2002; Schueler et al. 2011). The main actors are mining companies, industries using the minerals, and the growing urban population with its growing wealth, whose demand for new technologies has fueled increased mining activity. 
Institutional change at various scales affects these types of land-use competition and change. International institutions adopt new objectives, forms, and means of actions. Since the end of the Cold War, trade liberalization, the increasing recognition of ecological conservation, and perhaps even the new forms of international terrorism have altered the nature of conflict over land use and the institutions involved in them (Campbell et al. 2000; McLaughlin Mitchell and Hensel 2007). In land and environmental governance, economic instruments are increasing in prominence, as seen in the spread of carbon markets (e.g., Angelsen 2008), water quantity (Grafton 2011), quality markets (Shortle and Horan 2008), and PES schemes (Kinzig et al. 2011). Local cultures, knowledge systems, and land-use practices are increasingly influenced by environmental changes, urbanization, and the land-use competition processes described above.

\section{Mapping Land-Use Competition}

Mapping the spatial patterns of various types of land-use competition provides substantial opportunities:

1. to further our understanding of the processes involved in land-use competition (e.g., to uncover the actors involved in competing land uses, to identify regions affected by or prone to intense competition, or to detect strong or surprising telecouplings in land systems),

2. to improve the assessment of the impacts of land-use competition and the associated social and environmental trade-offs,

3. to unearth the spatial dynamics involved in competition (e.g., leakage effects, displacement),

4. to enhance our ability to foresee future types of competition and the locations where they could occur, and

5. to target policies that will mitigate or resolve land-use competition.

Mapping land-use competition globally, however, is challenging because some types of land-use competition take place on the plot level (e.g., a palm oil plantation replacing a natural forest), whereas others only become apparent further down the supply chain (e.g., maize to be used as feed, food, or feedstock for biofuel). Moreover, at the plot-level not all land-use changes are necessarily a result of land-use competition. Conversely, land-use competition can be prevalent even in regions where land use is stable. Table 4.2 outlines the opportunities and challenges for mapping the nine key land-use competitions.

Generally, mapping land-use competition requires two types of data at relatively fine spatial scales (grid level or small administrative units). First, information on land use is needed, both regarding the extent of land use (e.g., extent of cropping or forestry) and its intensity (e.g., labor, fertilizer). In this context it is important to note that information on all land uses is required, 
Table 4.2 Options and data needs for mapping the different types of land-use competition. Although the directionality of the competition may theoretically go both ways, the land-use competions listed below are suggested to play out primarily by the land use in italics replacing the other land use.

\begin{tabular}{|c|c|c|}
\hline Land-use competition & Datasets needed & Scale \\
\hline $\begin{array}{l}\text { Local food or feed } \\
\text { vs. } \\
\text { food for distant markets }\end{array}$ & $\begin{array}{l}\text { Crop type maps } \\
\text { Population density } \\
\text { Market data (or market accessibil- } \\
\text { ity maps as a proxy) }\end{array}$ & $\begin{array}{l}\text { Grid level or } \\
\text { administrative units, } \\
\text { global coverage }\end{array}$ \\
\hline $\begin{array}{l}\text { Traditional } \\
\text { multifunctional } \\
\text { vs. } \\
\text { agri-business }\end{array}$ & $\begin{array}{l}\text { Land systems map (e.g., Ellis 2011; } \\
\text { van Asselen and Verburg 2012) } \\
\text { Market data or market accessibility } \\
\text { Population density }\end{array}$ & Grid level \\
\hline $\begin{array}{l}\text { Food } \\
\text { vs. } \\
\text { feed }\end{array}$ & $\begin{array}{l}\text { Information on the actual use of } \\
\text { crops that can be used for feed or } \\
\text { food }\end{array}$ & $\begin{array}{l}\text { Administrative units, } \\
\text { global coverage (food- } \\
\text { producing regions) }\end{array}$ \\
\hline $\begin{array}{l}\text { Food or feed } \\
\text { vs. } \\
\text { bioenergy }\end{array}$ & $\begin{array}{l}\text { Information on the actual use of } \\
\text { crops that can be used for bioen- } \\
\text { ergy or other uses (feed/food) }\end{array}$ & $\begin{array}{l}\text { Administrative units, } \\
\text { global coverage (food- } \\
\text { producing regions) }\end{array}$ \\
\hline $\begin{array}{l}\text { Food or feed } \\
\quad \text { vs. } \\
\text { conservation }\end{array}$ & $\begin{array}{l}\text { Cropland extent and potential yields } \\
\text { Extent of protected lands (state- } \\
\text { owned and private reserves, areas } \\
\text { where REDD projects are imple- } \\
\text { mented, other set-aside land) }\end{array}$ & $\begin{array}{c}\text { Grid level, } \\
\text { global coverage }\end{array}$ \\
\hline $\begin{array}{l}\text { Conservation } \\
\text { vs. } \\
\text { timber extraction }\end{array}$ & $\begin{array}{l}\text { Logging in natural forests (either } \\
\text { actual harvests or a map of logging } \\
\text { concessions) } \\
\text { Extent of protected lands }\end{array}$ & Grid level \\
\hline
\end{tabular}

\begin{tabular}{cll}
\hline $\begin{array}{c}\text { Conservation } \\
\text { vs. } \\
\text { tree plantations } \\
\text { (for timber) }\end{array}$ & $\begin{array}{l}\text { Extent of tree plantations } \\
\text { Extent of protected lands }\end{array}$ & Grid level \\
\hline $\begin{array}{c}\text { Food or feed } \\
\text { vs. }\end{array}$ & $\begin{array}{l}\text { Urban extent } \\
\text { Cropland adjacent to cities } \\
\text { Mrban of cropland to urban } \\
\text { conversions }\end{array}$ & Grid level \\
\hline $\begin{array}{c}\text { Food or feed or } \\
\text { conservation } \\
\text { vs. }\end{array}$ & $\begin{array}{l}\text { Map of mining concessions and } \\
\text { pre-mining/current land use }\end{array}$ & Grid level \\
mining & & \\
\hline
\end{tabular}


including "nonproductive" land use such as protected or set-aside areas (such as REDD+ areas), indigenous territories, or private game reserves. Information on land tenure is also needed to provide information about how the land is used. Second, information on the characteristics of the land system is required, both in terms of land resources (e.g., soil fertility, water availability), which may spur the competition, and in terms of the socioeconomic attributes of the local area and broader region (e.g., tenure, market access) that influence the nature and intensity of the competition. In addition, if impacts or trade-offs of land-use competition are to be assessed, spatial information on the relevant environmental and human outcomes (e.g., biodiversity, carbon density, income inequality) is needed. Table 4.2 summarizes the data that would be needed for mapping each type of land competition.

\section{Implications of Land-Use Competition for Sustainability}

Identifying the implications of these various types of land-use competition for sustainability requires an articulation of the environmental and social tradeoffs that arise from the impacts of intensifying land-use competition. These impacts can be both direct (i.e., the result of the land-use competition at that location) or indirect (or cumulative, e.g., multimarket effects, spatial spillovers or cumulative effects across space and time). In addition, gains and losses of services may accrue to private actors: as additional revenues or costs to companies, farmers or individual land owners, or to public interests. The latter impacts accrue to society or a community as a whole rather than only to individual agents and include, for example, environmental damages, improved or degraded ecosystem services, and changing cultural landscapes. A full accounting of trade-offs considers all types of impacts: environmental and socioeconomic, direct and indirect, private and public. Table 4.3 reports observed and hypothesized impacts of the major types of land-use competition outlined in the previous discussion.

In many cases, land-use competition is brought on by private market forces and benefits primarily private interests while the costs are mostly borne by the public. For example, competition for agricultural land by urban use generates economic gains for individual land owners as they sell rural land for development, and for peri-urban farmers who improve their access to urban consumers and markets. However, urbanization also generates multiple environmental costs, including increased impervious surfaces and urban run-off, and social effects in terms of rural cohesion and livelihoods. Land sparing is a potential benefit: in China there is evidence that migration of rural populations to urban areas reduces rural residential land use and makes land available for agriculture (Huang et al. 2007b). In other cases, land is not preserved because urbanization is driven by suburban decentralization rather than rural to urban migration. 
Table 4.3 Impacts of various types of land competition on sustainability (ENV: environmental; SE: socioeconomic). Although the directionality of the competition may theoretically go both ways, the land-use competitions listed below are suggested to play out primarily when the land use in italics replaces the other land use.

\begin{tabular}{|c|c|c|c|}
\hline \multirow{2}{*}{$\begin{array}{c}\text { Types of } \\
\text { Competition }\end{array}$} & & \multicolumn{2}{|c|}{ Types of Impacts } \\
\hline & & Direct & Indirect (or Cumulative) \\
\hline \multirow{2}{*}{$\begin{array}{l}\text { Local food or feed } \\
\text { vs. } \\
\text { food for distant } \\
\text { markets }\end{array}$} & ENV & $\begin{array}{l}\text { Landscape heterogeneity; loss } \\
\text { of nonprovisioning ecosystem } \\
\text { services; environmental effects of } \\
\text { industrialized farming }\end{array}$ & $\begin{array}{l}\text { Changes in spatial } \\
\text { structure of land use (land } \\
\text { architecture) }\end{array}$ \\
\hline & SE & $\begin{array}{l}\text { Loss of livelihoods of smallhold- } \\
\text { ers; higher yields; higher volumes } \\
\text { of products }\end{array}$ & $\begin{array}{l}\text { Rebound effects of } \\
\text { increased efficiency and } \\
\text { availability of resources }\end{array}$ \\
\hline \multirow{2}{*}{$\begin{array}{l}\text { Traditional } \\
\text { multifunctional } \\
\text { vs. } \\
\text { agri-business }\end{array}$} & ENV & $\begin{array}{l}\text { Landscape heterogeneity; ecosys- } \\
\text { tem services }\end{array}$ & $\begin{array}{l}\text { Pesticides and nutrient } \\
\text { effluents; greenhouse gas } \\
\text { emissions related to fossil } \\
\text { fuels; potentially reduced } \\
\text { land demand }\end{array}$ \\
\hline & SE & $\begin{array}{l}\text { Increased volume of products; loss } \\
\text { of livelihoods of smallholders; } \\
\text { increased inequity }\end{array}$ & $\begin{array}{l}\text { Economic growth; oppor- } \\
\text { tunities to raise taxes }\end{array}$ \\
\hline \multirow[t]{2}{*}{$\begin{array}{l}\text { Food } \\
\text { vs. } \\
\text { feed }\end{array}$} & ENV & $\begin{array}{l}\text { Environmental impacts from inten- } \\
\text { sification of agricultural run-off in- } \\
\text { cluding nutrient run-off, pesticides, } \\
\text { soil degradation, etc. }\end{array}$ & $\begin{array}{l}\text { Expansion of farming to } \\
\text { new marginal land }\end{array}$ \\
\hline & SE & Increased land productivity & $\begin{array}{l}\text { Increased land prices; } \\
\text { changes in grain prices }\end{array}$ \\
\hline \multirow[t]{2}{*}{$\begin{array}{l}\text { Food or feed } \\
\text { vs. } \\
\text { bioenergy }\end{array}$} & ENV & $\begin{array}{l}\text { Reduction in greenhouse gas emis- } \\
\text { sions from fossil fuels; environ- } \\
\text { mental impacts from intensification } \\
\text { of agricultural production includ- } \\
\text { ing nutrient run-off, pesticides, soil } \\
\text { degradation, etc. }\end{array}$ & $\begin{array}{l}\text { Possible acceleration of } \\
\text { deforestation; may fail } \\
\text { to reach stated goals in } \\
\text { terms of greenhouse gas } \\
\text { emissions; spillovers push } \\
\text { other land uses outward }\end{array}$ \\
\hline & SE & $\begin{array}{l}\text { Increased food-security risks; loss } \\
\text { of livelihoods of smallholders; } \\
\text { higher food prices; increased land } \\
\text { productivity }\end{array}$ & $\begin{array}{l}\text { May induce innova- } \\
\text { tion and technology } \\
\text { development }\end{array}$ \\
\hline \multirow[t]{2}{*}{$\begin{array}{l}\text { Food or feed } \\
\text { vs. } \\
\text { conservation }\end{array}$} & ENV & $\begin{array}{l}\text { Preservation of valuable eco- } \\
\text { systems; ecological recovery of } \\
\text { degraded land }\end{array}$ & $\begin{array}{l}\text { Intensification of } \\
\text { nonconserved pasture } \\
\text { and cropland; displace- } \\
\text { ment of agricultural to } \\
\text { marginal lands; change in } \\
\text { hydrology }\end{array}$ \\
\hline & SE & $\begin{array}{l}\text { Increased access to ecosystem } \\
\text { services; change in cultural land- } \\
\text { scapes; new income sources for } \\
\text { local residents }\end{array}$ & $\begin{array}{l}\text { Higher agricultural land } \\
\text { rents }\end{array}$ \\
\hline
\end{tabular}

From "Rethinking Global Land Use in an Urban Era," edited by Karen C. Seto and Anette Reenberg. 2014. Strüngmann Forum Reports, vol. 14, J. Lupp, series ed. Cambridge, MA: MIT Press. ISBN: 9780262026901. 
Table 4.3 continued

\begin{tabular}{|c|c|c|c|}
\hline \multirow{2}{*}{$\begin{array}{c}\text { Types of } \\
\text { Competition }\end{array}$} & & \multicolumn{2}{|c|}{ Types of Impacts } \\
\hline & & Direct & Indirect (or Cumulative) \\
\hline \multirow{2}{*}{$\begin{array}{l}\text { Conservation } \\
\text { vs. } \\
\text { timber extraction }\end{array}$} & ENV & $\begin{array}{l}\text { Decline in natural habitats; decline } \\
\text { in nonprovisioning ecosystem ser- } \\
\text { vices; ecological succession; soil } \\
\text { acidification; decreased landscape } \\
\text { diversity }\end{array}$ & $\begin{array}{l}\text { Potentially large-scale } \\
\text { cumulative effects on re- } \\
\text { gional hydrology; carbon } \\
\text { emissions }\end{array}$ \\
\hline & SE & $\begin{array}{l}\text { Increased risks for food security; } \\
\text { new income source for local work- } \\
\text { ers; more nonfood products from } \\
\text { forestry }\end{array}$ & $\begin{array}{l}\text { Economic growth; oppor- } \\
\text { tunity to raise taxes }\end{array}$ \\
\hline \multirow{2}{*}{$\begin{array}{l}\text { Conservation } \\
\text { vs. } \\
\text { tree plantations } \\
\text { (for timber) }\end{array}$} & ENV & $\begin{array}{l}\text { Decline in natural habitats; decline } \\
\text { in nonprovisioning services; eco- } \\
\text { logical succession; soil acidifica- } \\
\text { tion; decreased landscape diversity }\end{array}$ & $\begin{array}{l}\text { Potentially large-scale } \\
\text { cumulative effects on re- } \\
\text { gional hydrology; carbon } \\
\text { emissions }\end{array}$ \\
\hline & SE & $\begin{array}{l}\text { Increased labor demand and thus } \\
\text { rural wages; deterioration of } \\
\text { livelihoods for forest-dependent } \\
\text { people }\end{array}$ & $\begin{array}{l}\text { Economic growth; } \\
\text { opportunities to raise } \\
\text { taxes; potential sparing of } \\
\text { natural forests }\end{array}$ \\
\hline \multirow[t]{2}{*}{$\begin{array}{l}\text { Food or feed } \\
\text { vs. } \\
\text { urban }\end{array}$} & ENV & $\begin{array}{l}\text { Increased impervious surfaces and } \\
\text { urban run-off; reduced agricultural } \\
\text { run-off; potential land sparing if } \\
\text { rural residents abandon land when } \\
\text { moving to city; less reversibility } \\
\text { in land use; loss of ecosystem } \\
\text { services }\end{array}$ & $\begin{array}{l}\text { Increased temperatures in } \\
\text { microclimate }\end{array}$ \\
\hline & SE & $\begin{array}{l}\text { Loss of rural lifestyle and culture; } \\
\text { increased incomes for rural land- } \\
\text { owners selling land; greater oppor- } \\
\text { tunities for (peri)urban agriculture }\end{array}$ & $\begin{array}{l}\text { Increased concerns about } \\
\text { food security }\end{array}$ \\
\hline \multirow{2}{*}{$\begin{array}{l}\text { Food or feed or } \\
\text { conservation } \\
\text { vs. } \\
\text { mining }\end{array}$} & ENV & $\begin{array}{l}\text { Decline in natural habitats; decline } \\
\text { in nonprovisioning ecosystem } \\
\text { services }\end{array}$ & \\
\hline & SE & $\begin{array}{l}\text { Increased labor demand and } \\
\text { wages; possible effects on local } \\
\text { food security }\end{array}$ & \\
\hline
\end{tabular}

Other types of land-use competition generate a more complex set of tradeoffs across human and biophysical systems and private and public interests. In the case of agricultural land competition for bioenergy production, one motivation is to reduce greenhouse gas emissions, which is in the public interest. However, the resulting land-use competition may also result in environmental costs if food crop production moves somewhere else, perhaps driving deforestation ("indirect land-use change"), thereby undermining the stated goals, and 
sometimes creating detrimental effects for other public interests (e.g., biodiversity). Expanded bioenergy production may also imply economic trade-offs, by inducing increases in agricultural productivity, which raises the incomes of farmers but reduces food or feed crop availability and may ultimately drive up food prices. The latter is a pecuniary externality ${ }^{1}$ caused by the reduction in food supply, which generates a public cost —one that is especially large for poor households that have a low elasticity of demand for food.

These examples illustrate the potential complexity of the trade-offs related to land-use competition. Any assessment in terms of sustainability thus requires an understanding of the dynamic socioeconomic and environmental processes and their interactions that generate both the direct and indirect impacts listed in Table 4.3. Doing so requires not only data and mapping, but also the development of models to permit a better understanding of these system dynamics and assessment of these impacts and their trade-offs (Figure 4.1; see also the discussion on institutions by Eakin et al., this volume). However, our understanding of the environmental and socioeconomic processes and their interactions is limited both by a lack of data and scientific understanding as well as the inherent uncertainty of dynamic systems. Thus accounting for uncertainty in assessing trade-offs and sustainability is critically important.

\section{Managing Land-Use Competition}

\section{Governance, Land Management, and Institutions}

Institutions evolve from specific contexts to address particular challenges and are partly determined by culture and history. Institutions can have a large influence on the way land-use competition occurs as well as on its outcomes. In this section we propose a framework to identify mismatches between institutions and the land-use competition they mediate. By "institutions" we mean a wide range of organizations and formal or informal rules that influence decisions. ${ }^{2}$

A large scholarly literature has emerged on how institutions affect land management, for example related to the governance of common lands (Ostrom 1990), urban land and sustainable cities (Bai et al. 2010; Evans et al. 2004),

1 Pecuniary externalities operate within the market as opposed to technological externalities (e.g., environmental degradation) which generate effects external to the market. Pecuniary externalities arise when markets are related (e.g., through input and output linkages) and a change in one market generates price effects in a related market. Because these price effects are external to individuals, they are considered externalities and can be counted as public costs (e.g., for consumers in the case of a price increase) or benefits (e.g., for producers in the case of a price increase).

2 Turner (1997:6) defines an institution as "a complex of positions, roles, norms, and values lodged in particular types of social structures and organizing relatively stable patterns of human activity with respect to fundamental problems in producing life-sustaining resources, in reproducing individuals, and in sustaining viable societal structures within a given environment." 
agricultural land and production systems (Binswanger et al. 1995; Deininger and Feder 2001; Palmer et al. 2009; Stavins et al. 1998), management of conservation and protected areas (Joppa and Pfaff 2011), PES (Jack et al. 2008; Wunder et al. 2008; Robalino et al. 2008), or REDD+ (Angelsen 2010; Kerr 2013; Lubowski and Rose 2013; Matthews and Dyer 2011). Since Hardin's (1968) claim - land used for production that is neither private nor under government control inevitably degrades due to the "tragedy of the commons"it has been repeatedly demonstrated that resources held by local commons (i.e., that is communally owned and used) are often managed efficiently and sustainably (Ostrom 1990, 1999). Moreover, it has been shown that private owners can degrade their land (Kirby and Blyth 1987) and that the same can happen with command economy institutions, as in the case of the Aral Sea (Micklin 1988).

There are examples of both successful (e.g., the U.S. Conservation Reserve Program, which initially had problems but gradually evolved; Roberts and Lubowski 2007) and unsuccessful institutions (e.g., the initial form of the PES system in Costa Rica; Sánchez-Azofeifa et al. 2007) created to mediate specific cases of land-use competition. Many cases exist in which institutions fail to resolve competition in ways that are successful, and no single institutional form (or set of institutions) has emerged to solve all problems. Within environmental economics, there is considerable literature on "instrument choice" within developed countries (Stavins et al. 1998) that discusses which instrument best addresses environmental issues under which circumstances.

\section{Types of Institutions and Their Functions: Conceptual Considerations}

Here we focus on what the types of land-use competition identified above require in terms of the structure and functioning of institutions to regulate competition among land uses (see also Gentry et al., this volume). Potentially new directions of research are discussed using two examples: competition between (a) food and feed and (b) food and urban areas.

Institutions can have a combination of organizational "functions." Institutions may be able to set society's agenda and define objectives, which could be a combination of environmental, economic, and social outcomes or impacts. Institutions can act to protect interests, share resources, and aim at a more equitable distribution of resources. Laws (and the institutions that enforce them) mostly protect existing defined property rights. In cases where property rights or sharing rules are poorly defined, "community" institutions can play a role in finding a consensus. Alternatively, private actors could claim these poorly defined resources and cause costs that were not agreed to by society more widely. Institutions will affect how efficiently or effectively objectives are achieved once they are set.

Based on these distinctions, we offer an analytical framework (Table 4.4), in the form of a matrix, to help explore how institutions do and could affect 
Table 4.4 Conceptual framework for analyzing institutions and their functions in mediating land-use competition, with an example for water quality trading in Lake Taupo, New Zealand. For more information on the system, see Duhon et al. (2012).

\begin{tabular}{|c|c|c|c|}
\hline \multirow{2}{*}{$\begin{array}{c}\text { Types of } \\
\text { Institutions }\end{array}$} & \multicolumn{3}{|c|}{ Functions } \\
\hline & Define objectives & Distribution/equity & Effectiveness/efficiency \\
\hline \multicolumn{4}{|l|}{ Government: } \\
\hline Scientists & $\begin{array}{l}\text { Provided evidence } \\
\text { on historic leach- } \\
\text { ing and lake qual- } \\
\text { ity and projections } \\
\text { without control }\end{array}$ & & $\begin{array}{l}\text { Provided consistent moni- } \\
\text { toring tool that enabled use } \\
\text { of economic instrument } \\
\text { Continue to develop mitiga- } \\
\text { tion options }\end{array}$ \\
\hline $\begin{array}{l}\text { Regional } \\
\text { council }\end{array}$ & $\begin{array}{l}\text { Jointly deter- } \\
\text { mined goal of }\end{array}$ & $\begin{array}{l}\text { Negotiated tree allo- } \\
\text { cation to farmers and } \\
\text { Maori and paid for } \\
\text { some reductions }\end{array}$ & $\begin{array}{l}\text { Designed and implemented } \\
\text { first non-point-source water } \\
\text { quality trading system }\end{array}$ \\
\hline $\begin{array}{l}\text { Central } \\
\text { government }\end{array}$ & $\begin{array}{l}\text { no deteriora- } \\
\text { tion in quality }\end{array}$ & $\begin{array}{l}\text { Provided share of } \\
\text { funds to buy back } \\
\text { leaching allowances }\end{array}$ & $\begin{array}{l}\text { Provided overall legal } \\
\text { structure; Resource Man- } \\
\text { agement Act }\end{array}$ \\
\hline
\end{tabular}

Private:

\begin{tabular}{lll} 
Farmers & $\begin{array}{l}\text { (Ultimately) ac- } \\
\text { cepted the need } \\
\text { for control }\end{array}$ & $\begin{array}{l}\text { Changed land use and miti- } \\
\text { gated leaching on farms; } \\
\text { engaged in trade }\end{array}$ \\
$\begin{array}{l}\text { Agricultural } \\
\text { consultants }\end{array}$ & $\begin{array}{l}\text { Assisted in compliance and } \\
\text { disseminated mitigation } \\
\text { options }\end{array}$ \\
\hline
\end{tabular}

Community:

$\begin{array}{llll}\begin{array}{l}\text { Landowners' } \\ \text { groups }{ }^{1}\end{array} & \begin{array}{l}\text { bates on different } \\ \text { structures for free } \\ \text { allocation }\end{array} & \begin{array}{l}\text { Advocated for flexible } \\ \text { instruments }\end{array} \\ \text { Iwi (local } & \begin{array}{l}\text { Advocated for } \\ \text { protection of lake }\end{array} & \begin{array}{l}\text { Negotiated for } \\ \text { protection of their } \\ \text { interests - current } \\ \text { low emitters }\end{array} & \\ \text { Maori tribe) } & \text { Ensured that all } & \text { Identified and negotiated } \\ \text { Protection } & & \text { traders are well } & \text { buy-back of allowances } \\ \text { Trust } & \text { informed } & \end{array}$

1 Mike Barton (2005), a local beef farmer, played a key role in coordinating the local voice. 
situations where there is "complex" land-use competition. In particular, we are looking for new or exacerbated situations of land-use competition where existing institutions are leading to outcomes that are considered unfavorable. "Complex" could involve multiple jurisdictions (local to international), multiple services (production, biodiversity), and/or multiple actors in unusual connections (e.g., local landowners and households in Africa being affected by dietary choices in Europe in a contest between growing food to eat directly and feed for animals). By "institutions" we mean a wide range of organizations and rules (formal or informal) that aim to influence outcomes. We have grouped institutions as follows:

- those who have some formal power to coerce and some responsibility to represent a wider group,

- those primarily motivated by the interests only of their group, and

- those with an interest beyond their own but without strong coercive power.

We recognize that these are not clear distinctions and that some organizations will be hard to classify and may be differently classified in different applications. This framework is not intended to provide a taxonomy. Some examples are:

- "Government": national, local, and regional elected government bodies, government departments, laws, regulations, international agreements, and corrupt politicians.

- "Private sector": Companies, multinationals, smallholders, and private market institutions (e.g, banks, insurance companies).

- "Community": NGOs, media, universities, cultural norms, church, and family.

One way to use the matrix is to take one of the important land-use competition types identified above and its sustainability implications, identify the institutions currently involved and how their objectives have affected the overall objectives sought in this competition (that become "drivers" and desired outcomes), and the distributional and efficiency outcomes. This may help identify the source of any undesired outcomes, either through dominant power in specific institutions or weakness or absence of another institution.

To illustrate, Table 4.4 shows the set of institutions involved in the creation of the first non-point-source cap and trade water quality market in New Zealand. Together the institutions successfully defined the objectives and reached agreement on distributional issues while creating a potentially efficient mechanism. Looking forward we can compare critical institutional needs with the available institutions to diagnose likely challenges. One problem that may arise is that the compliance mechanisms available to the regional council are uncertain and weak (each noncomplier must be taken to court). This is likely to create problems when the cap becomes strongly binding. Solving this 
requires changing the Resource Management Act, which can be done only by the central government.

\section{Example 1: Governance Challenges Related to Food versus Feed Competition}

At present, there is a global trend toward greater consumption of animal products per capita, and this has substantial, growing impacts on greenhouse gas emissions, land use, and other environmental effects (Pelletier and Tyedmers 2010; Steinfeld et al. 2006; Wirsenius et al. 2010). As identified above, if diet change continues to involve increased animal products, more land will be needed for animal production for grazing or feed crops (Haberl et al. 2011a; Erb et al. 2012).

When seen from a large (regional or global) level, this is a significant environmental issue due to the increasing land demand that it creates as well as the thermodynamic inefficiency of converting feed to animal products. It will raise the price of agricultural land and increase the price of other agricultural products, especially food. Land owners are likely to benefit, but those who need to buy food, especially the very poor who eat little or no meat, are likely to lose. Indirectly, at a global scale, pressure to use land for agriculture and to intensify production will increase. This will tend to decrease conservation land, thus putting more pressure on natural ecosystems. If poorly managed, it will also reduce ecosystem services that are essential for ongoing production of food and feed, and thus will be unsustainable even in the narrow sense. Locally, in some cases, if local markets are not integrated globally or with other regions, a shift from food to feed production might affect local food prices. Mostly, however, the effects on food and land prices and environmental outcomes are likely to be indirect and global rather than direct and local. When, for example, one crop switches from one to the other use, or the same field is planted with another crop, the impacts at a local level are likely to be limited. For actors that have environmental interests on the local scale, the use of the crop is probably not a priority, and the effects on local food prices are small relative to the economic benefit from responding to the demand for feed. The cumulative global effects, however, can be large and potentially important (Steinfeld et al. 2006). Thus, the governance challenge is to manage this global-scale competition in such a way that it is acceptable and can be implemented at the local scale.

The increased demand for feed is driven by consumption patterns and affected by institutions within markets that coordinate the production and distribution of food. Consumption drivers are largely at an international scale and, other than population and general rises in material well-being, might include cultural influences such as the media. While there are some examples of institutions acting to change or enforce some diets (e.g., WHO diet recommendations), few institutions deliberately address the environmental implications of increased meat demand. Local responses are more likely to be driven by social concerns 
(e.g., the landless movement protesting growing food insecurity), while in distant consumer places environmental issues might be more important. Important knowledge gaps exist regarding how changes in information, media, or incentives (such as a tax on the consumption of animal products) would affect food production and consumption decisions at local and global scales.

\section{Example 2: Governance Challenges Related to the Competition between Food/Feed Production versus Urban Land Expansion}

As described above, urban encroachment on cropland pushes food production for city dwellers further away. Given the historical location of cities, encroachment onto "prime agricultural land" often occurs and can be very costly to reverse. The direct effect of this land transition is a different set of environmental impacts that are generated by the city relative to the previous impacts from food production. On a larger scale, urbanization implies that people move away from rural areas, which can reduce environmental pressure in these areas. The net impacts are, however, unclear: food and environmental impacts may simply have moved or, if urban dwellers have a lower "land footprint," then overall pressure can be reduced. The main actors are private land owners, land developers, local authorities who define zoning constraints and make decisions on infrastructure, and farmland conservation NGOs. Many of the issues related to these institutions have been well studied (Cheshire and Sheppard 2002; Fischel 1985; Glaeser and Ward 2009), especially in the developed world. New institutional responses to urban land demand include, for example, the "food mile" critique, which originally applied a simplistic approach to assess the environmental costs associated with long-distance transportation. Later assessments pointed out, however, that reducing long-distance transportation may, in some cases, even increase emissions if it results in larger production emissions, as the latter are usually much larger than the emissions related to transport (Weber and Matthews 2008; Blanke and Burdick 2005). This may be the case, for example, if local production results in higher greenhouse gas emissions due to unfavorable soil or climate conditions. This demonstrates why policies need to be based on accurate and comprehensive indicators so as to avoid creating unintended detrimental effects.

\section{Incremental versus Transformative Changes in Land-Use Governance}

The above examples show that (a) what looks like a competition between food and feed at local scale may also involve competition between production and conservation at the global level and (b) by solely focusing on some social or environmental impact, new institutions to manage competition might produce unintended counterproductive consequences (e.g., "food miles"). Thus policies which seek to manage the impacts of various types of land competition 
must account for the variety of social and environmental trade-offs that exist across multiple scales. This complexity requires new institutions to manage these trade-offs as well as to encourage synergies among land uses whenever possible. One question that arises is the extent to which we need some form of global governance to manage land competition. Obviously, many aspects of the governance of land use and land-use competition will remain at the local or national level. For example, many issues of food security involve not only overall production or efficiency but distribution, access, and other issues that concern national governments. The question is: Which aspects, issues, and decisions might be addressed more appropriately on the global level, and how might global land governance emerge? Who could benefit from some form of global land governance?

Some forms of global land governance might emerge from biophysical and environmental concerns (e.g., in terms of land set aside for habitats) whereas other forms might emerge from social issues (e.g., related to global food systems) (see Margulis as well as Gentry et al., this volume). Other innovative ways to address land-use competitions might be explored, such as forms of land allocation or land resource quotas per individual or household. However, this raises serious issues, including question of scale, social acceptability of such approaches, and the technical difficulties involved in accounting for the resources necessary for each product. Other approaches might directly constrain production or provide incentives to producers by assessing, for example, a sustainability user cost for resource extraction.

\section{Land Competition in the Context of Long- Term Transitional Dynamics}

Global population growth, shifting consumption patterns and dietary habits, and growing economic activity (GDP) are major drivers of long-term expansion of urban areas, croplands, pastures and secondary vegetation at the expense of primary (natural) vegetation (Figure 4.3a; Hurtt et al. 2011; see also van Vuuren et al. 2012). The underlying causes for the changes in the volume and pattern of resource demand are ongoing transitions from agrarian to industrial societies (Haberl et al. 2011b). While this transition may seem to be more or less completed in industrialized countries, it is taking off rapidly in developing regions (e.g., in China and India; Fischer-Kowalski and Haberl 2007), where it currently affects more than two-thirds of the world population. The agrarian-industrial transition results in surging global resource use (Figure 4.3b; Krausmann et al. 2009) and greenhouse gas emissions (Canadell et al. 2007), hence triggering growing concerns about resource scarcity (GEA 2012) and changing global biogeochemical cycles and the global climate (IPCC 2007). 
(a)

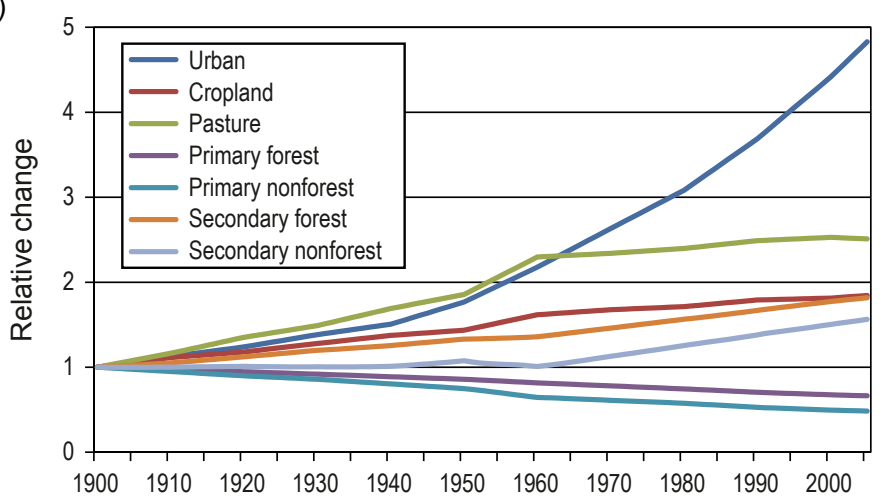

(b)

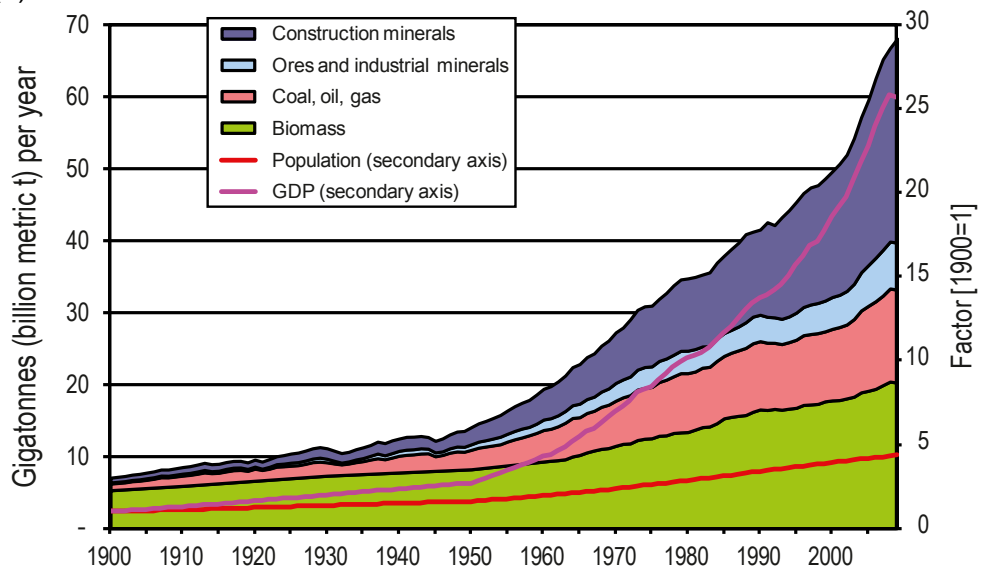

Figure 4.3 (a) Global land-cover change relative to 1900 (data from Hurtt et al. 2011). (b) Global use of materials compared to increases in the gross domestic product (GDP) and population (data from Krausmann et al. 2009, updated with data from http://www. uni-klu.ac.at/socec/inhalt/3133.htm). Left axis: global resource use $\left(10^{9}\right.$ metric tons per year). Right axis: growth in population and GDP during the same interval $(1900=1)$; GDP is measured in constant 1990 Geary-Khamis dollars.

These global sustainability challenges have not only motivated a new growth critique and the search for new welfare models (Jackson 2009) - issues outside the scope of this chapter - they are also bound to affect land systems in many ways. Furthermore, major global assessment reports (MEA 2005; GEA 2012; IPCC 2007; IAASTD 2009) suggest that the ongoing trajectory cannot be followed long term without causing massive biodiversity loss, soil degradation, resource shortage, and climate change. Thus, humanity faces a key challenge in how it will feed healthily and sustainably a future global population of 9 billion (Smith et al. 2010). 
Competition for land is not in itself a driver that affects food and farming in the future, but is an emergent property of other drivers and pressures. Thus land-use competition arises from the above described transition from agrarian to industrialized societies. Some of the new types of land-use competition outlined above are a result of the sheer scale of these processes (e.g., those related to urbanization, the demand of land from mining, or increases in food production). Others are a result of policies aimed at addressing some of these challenges (e.g., the emergence of conservation and a major type of land use with the power to compete with other types of land use, such as food production or the competition between food/feed and bioenergy).

Over the last century, the rate of expansion of farmland (cropland and grazing land) was substantially lower than that of population, GDP, or food provision. This "decoupling" was achieved through a combination of increases in yields, on the one hand, and increases in conversion efficiencies from primary biomass harvest to final product supply, most notably those of feeding efficiencies (i.e., the amount of feed required per unit of animal product) on the other (Erb et al. 2012; Haberl et al. 2011a; Krausmann et al. 2009). Taken together, these increases in yield growth and biomass conversion efficiency were large enough to allow for increased per capita food supply, in terms of both calories and animal protein, as well as a reduction in malnutrition and hunger, at least until the food price surges in 2007 (Godfray et al. 2010). These efficiency increases have contributed to reduce deforestation and greenhouse gas emissions (Burney et al. 2010), although the actual effect is difficult to determine since population and per capita food consumption respond to increasing supply (Lambin and Meyfroidt 2011; see also Lambin and Meyfroidt, this volume). Increases in yield and conversion efficiencies are generally expected to continue over the next decades. Most global projections of the current generation of global assessment models project that (a) global demand for agricultural products will rise by $70-100 \%$ until 2050 and (b) most of that increase will come from increases in yields and conversion efficiency; cropland areas, by contrast, are expected to grow only moderately, perhaps by some 6-19\% until 2050 (Coelho et al. 2012; FAO 2006; MEA 2005; Tilman et al. 2011). Future projections thus indicate only a moderate growth in farmland. This picture may well change, however, if the expected yield growth does not materialize, if bioenergy were to play a major role in the future, or if expected future trajectories of demand were to shift, as discussed below.

\section{Limits to Continued Agricultural Intensification}

While many scenarios and official forecasts more or less project past yield gains into the future, as shown in the examples cited above, several developments could counteract a continuation of past yield growth. First, yields could approach physiological limits in some regions (Cassman 1999; Peng et al. 2000; Tilman et al. 2002). Likewise, the most suitable agricultural lands in some 
regions are already in use, and thus further agricultural expansion would occur on land less suited; soil erosion and depletion of nutrient stocks could also hamper yield growth. Together, this suggests that yield increases could slow down in the future. While improved management might help to sustain yield growth (IAASTD 2009; Coelho et al. 2012), substantial investments would be necessary to maintain yield increases (Kahn et al. 2009). In addition, past improvements in land-use efficiency depended on the availability of abundant energy to run agricultural machinery as well as for the production of fertilizers and pesticides (Pimentel et al. 1990; Krausmann et al. 2003). Energy scarcities could reduce the future growth of yields. Finally, organic agriculture is arguably associated with important environmental benefits compared to conventional, industrialized farming (e.g., lower impacts on biodiversity, lower nutrient runoff or leaching, increased soil quality; IAASTD 2009). However, the yields of organic agriculture are substantially below those of intensive, industrialized farming, especially when the whole crop rotation cycle is taken into account (Seufert et al. 2012). Thus, an expansion of organic agriculture would result in a larger demand for farmland, unless this is accompanied by a simultaneous change in diet toward a more vegetarian diet (Erb et al. 2012).

\section{Changes in Demand for Land-Based Services and Products, in Particular Bioenergy}

So far, income growth has been almost universally associated with dietary changes toward a higher share of animal-based products (Haberl et al. 2011a, 2012). Analyses of regional time series of dietary change suggest that the consumption of animal products tends to stagnate in affluent regions such as in the United States and Europe, whereas it continues to grow in developing regions (Coelho et al. 2012). Changes in diets toward fewer animal products could help to reduce emissions significantly (Tukker et al. 2011; Stehfest et al. 2009; Wirsenius et al. 2010), as well as farmland demand, and thus lead to a relaxation of land-use competition (Erb et al. 2012; Popp et al. 2010; Smith et al. 2013; Stehfest et al. 2009).

Rising fossil energy prices, growing concerns about resource scarcity and nuclear risks, and increasing attemps to reduce $\mathrm{CO}_{2}$ emissions are motivating policies to develop renewable energy sources, including hydro and wind power, geothermal energy, and different types of bioenergy (solid, liquid, or gaseous). While all renewable energy technologies require land (and may hence result in land-use competition), area demand per unit of energy is by far largest in the case of bioenergy (Coelho et al. 2012). Some studies even suggest that up to $36 \%$ of all land (except Greenland and Antarctica) could be used for bioenergy production (Smeets et al. 2007) - an area similar to that currently farmed for food and fiber. Less ambitious bioenergy supply targets, including those put forward by major global assessments, would still require the cultivation of 
energy crops on some $2-10 \%$ of all land (Beringer et al. 2011; Haberl et al. 2010; van Vuuren et al. 2009; Chum et al. 2012; GEA 2012).

Embarking on such policies would change the global land system fundamentally because global energy demand is practically unlimited compared to the capacity of terrestrial ecosystems to supply biomass (i.e., their net primary production, $\mathrm{NPP}^{3}$ ). Once biomass becomes competitive on the energy market, the very structure of agricultural commodity markets will likely change substantially (FAO 2009a). Moreover, surging biofuel production would entail major land-use and land-cover changes, mainly in the developing world (Danielsen et al. 2009; Warren 2011) and at the expense of forests and pastures (Mbow 2010). This would significantly reduce the mitigation effect of biofuel; forest loss could even alter the greenhouse gas balance (replacing fossil fuels with bioenergy) from savings to an increase (Lapola et al. 2010; Searchinger 2010).

Land required for sequestration and storage of carbon represents another type of demand. The challenge is to know how much land-based greenhouse gas mitigation can be achieved without compromising food security and environmental goals (Smith et al. 2013). These issues point to the need of scrutinizing the social and ecological impact of pursuing global climate change goals without nesting it to local land needs and development priorities. Land-use policies based on environmental zoning approaches can be beneficial in this context (Coelho et al. 2012; Macedo et al. 2012). At present it is unknown whether, where, and under which circumstances use of land for bioenergy or carbon sequestration provides greater benefits in terms of greenhouse gas reduction (Smith et al. 2013).

\section{Climate Change Effects and Adaption to Climate Change}

Land use is strongly influenced by climate change (Giannini et al. 2008; van Vuuren et al. 2011). Changes in rainfall and temperature modify growing conditions and primary productivity (Pettorelli et al. 2005; Fensholt et al. 2009; Hiernaux et al. 2009; Zhao and Running 2010) and may affect yields negatively or positively. Unfortunately, there are very large knowledge gaps and uncertainties with respect to many important potential impacts, in particular the magnitude of a possible $\mathrm{CO}_{2}$ fertilization effect as well as its interaction with land management, nutrient availability, and yields (Haberl et al. 2011a). Moreover, the need to adapt to climate change will require modifications in land-management practices toward improved resilience to climate fluctuations and other climate changes. This may include the diversification of cultivars, changes in pasture management, adoption of new production systems, and changes in sowing dates (Waha et al. 2012). In developing countries, there is

3 Aboveground terrestrial NPP is approximately double humanity's total energy needs, including food and feed (Haberl et al. 2011a). 
growing agreement that agroforestry (i.e., the integration of trees with crops and livestock systems) offers a good strategy for improving soil properties and increasing yields, while at the same time improving nonprovisioning ecosystem services and bioenergy production and limiting the human impact on remaining forests (Smith and Wollenberg 2012). Agroforestry may also be one particularly rewarding option to help sequester carbon and reduce greenhouse gas emissions that result from land-use change (Zomer et al. 2009). Adapatation of land use to current and future climate change is an emerging research area that goes beyond carbon-related issues.

\section{A Long-Term Perspective on Land Demand for Conservation}

Several considerations suggest that land demand for conservation may increase also in the medium to long term. Climate change mitigation has motivated initiatives for substantially increasing global forest cover (e.g., REDD+, the clean development mechanism, and national afforestation programs) (Mertz 2009; Alig et al. 2010). Indeed, ambitious climate change mitigation scenarios mostly require "negative" carbon emissions in the second half of the twentyfirst century (van Vuuren et al. 2011), and increasing carbon stocks in forests is an option to achieve negative emissions as is the combination of bioenergy with carbon capture and storage (Popp et al. 2011).

Another reason why land demand for conservation may be assumed to rise over the long term is related to ecosystems and biodiversity. Long-term environmental change includes the loss of biodiversity, which in turn affects ecosystems services and functions (Toit et al. 2004; Mbow et al. 2010; Gonzalez et al. 2012). Although the interactions between biodiversity and ecosystem services are widely, and controversially, debated, there are concerns that their possible links with critical "tipping points" could lead to large, rapid, and potentially irreversible changes in land cover or land productivity. The Global Biodiversity Outlook (GBO3) has adopted the concept of tipping points to better understand trends in biodiversity. Climate change is thought to be a strong driver of biodiversity loss, which in turn would likely have irreversible consequences for ecosystem functions and services (Mooney et al. 2009; Pimm 2009). It has therefore been argued that long-term strategies need to be implemented to conserve biodiversity and ecosystems and avoid long-term detrimental effects of biodiversity loss (MEA 2005).

Both climate change and biodiversity conservation are likely to remain on the agenda for the near foreseeable future, thereby creating increasing funds, economic opportunities, and institutions to devote land for conservation activities worldwide, but particularly in developing countries (Rosendal and Andresen 2011). These concerns may well be exacerbated by a growing

4 "Tipping point" commonly refers to a critical threshold at which a tiny perturbation can qualitatively alter the state or development of a system (Lenton et al. 2008). 
recognition of water scarcity and limits to water resources, for example due to the water demand of bioenergy crops or the overexploitation of groundwater resources in many large aquifers, especially in Asia and North America (Gleeson et al. 2012). Competition for water and land are linked processes; they may reinforce one another and contribute to further growth of ecological injustice between rich and poor regions (Coelho et al. 2012).

\section{Knowledge Gaps}

The novel challenges of increased land-use competition in a rapidly urbanizing and more teleconnected world poses a large array of important research questions and knowledge gaps. In this section we highlight some that emerge from the above discussion.

\section{Future Interaction of Land and Energy Systems}

The many types of competition between land uses and future trajectories of urbanization are strongly related to changes in energy supply. Hence one emerging scientific challenge is to underpin strategies that better manage agriculture and land use in an increasingly energy-scarce world. For example, there are complex trade-offs between the socioecological costs and benefits of land-use intensification and increased adoption of organic agriculture. While there are obvious trade-offs between food production, bioenergy production, and the use of land for carbon sequestration and biodiversity conservation (Erb et al. 2012), there are also possible synergies from an integrated optimization of food and bioenergy supply chains, for example, through use of agricultural residues or waste flows (Haberl and Geissler 2000; WBGU 2009). All these complex feedback processes will likely be strongly affected by climate change impacts (e.g., the impacts of climate change on food, feed, and energy crop yields; Haberl et al. 2011a), which at present are poorly understood, in particular due to the difficulties in modeling the responses of farmers to changes in temperature, water availability, or extreme events (e.g., Waha et al. 2012). Although a move toward less energy consumption and environmentally less demanding and more healthy diets poses few, if any, risks of detrimental environmental feedbacks, it has been notoriously difficult to achieve such changes through political action or institutional change (Haberl et al. 2011b). Some views argue for a world where energy efficiency would increase with agricultural improvements, hence leading to an agriculture system where production would be centralized (and concentrated in a very few places); this would result in high efficiency and therefore reduce the competition for land or conversion to other uses. 


\section{Finite Land Resources and Tipping Points}

Overall, care must be given to the underlying assumption that society is about to reach the productive land limits of Earth. History is marked by many illfated pronouncements that such limits were about to be breached. While land limits and productive limits are real, what constitutes prime agricultural land has long been contingent on the management strategies and technologies employed, which in turn are contingent on political and economic conditions (e.g., advances made in tropical agriculture relative to past views about the paucity of productivity of many tropical soils). "Finite," perhaps, is better understood in terms of the negative human-environment trade-offs among competing land uses (Lambin 2012) and the possibility that the totality of land changes may reach thresholds or tipping points that affect the functioning of ecosystems or the Earth system as a whole. In particular, priority should be given to improving our understanding of the systemic linkages between biodiversity, ecosystem services, land-use change, and climate change, given rapidly growing greenhouse gas emissions, strong increases of demand, and the lack of success in both biodiversity and climate change mitigation policies.

\section{Land Architecture}

The future of land dynamics will increasingly be affected by complex tradeoffs (and synergies) among multiple land-use/cover units. Mosaics of these units constitute a land system, in which the number, kinds, size, shape, distribution, and connectivity of the units constitute the architecture. This architecture and the associated trade-offs affect human and environmental wellbeing. Understanding the human and environmental outcomes of land system architectures - from the urban center to the distant wildlands - is necessary to evaluate which alterations of the architecture will provide societal preferences in a more sustainable manner (Chan et al. 2006; Goldstein et al. 2012; Polasky et al. 2005). To improve understanding requires attention to the interactions among land units within the land system, including all of the dimensions noted above as well as interactions among different land systems. To date, assessments of full land system architecture are unavailable, but partial assessments (either of a few land units or a few trade-offs) provide clues that the architecture matters. Recent work, for example, shows that the design of green spaces in Beijing affects its urban heat island (Li et al. 2012), whereas the design of mesic neighborhoods and commercial areas in Phoenix affects land-surface temperature as does the urban design in Baltimore (Connors et al. 2013; Zhou et al. 2011). In terms of rural wildland, local-to-regional precipitation is affected by the architecture of deforestation, the size and distributions by which forest patches are cut (Malhi et al. 2007). The landscape level might often be appropriate to balance the trade-offs between competing land uses and 
maximize the synergies and multiple functions of land (Fischer et al. 2008; Koh et al. 2009).

\section{Need for Multiscale Models to Assess Local- Global Connections and Impacts}

Improved governance requires an assessment of trade-offs, beyond the general summary of impacts presented in Table 4.3, and must include a quantitative assessment using careful empirical analysis with the necessary data. Many case studies of specific land-use changes have been done (Lambin and Geist 2006). While the development of local case studies is critical for understanding the place-specific set of constraints and attributes that influence land-use competition and its impacts, understanding the sustainability impacts of changing land-use systems on a global scale requires much more. Global integrated assessment models are useful for understanding the direct and indirect impacts of price changes on input and output markets, including changes in land used in the production of agriculture or forest commodities. However, space is highly aggregated in these models and thus it is not possible to articulate how local impacts, which may be quite heterogeneous across space, aggregate up to regional or global scales. To answer the question of global impacts and feedbacks, an understanding of how changes at the global scale (e.g., due to consumer demand or technological adoption) influence local land-system changes is necessary. For example, Verburg et al. (2008) developed a multiscale, multimodel approach for analyzing future land-use changes in Europe. In this approach, flows of economic inputs and outputs within Europe are, on one side, nested within global flows, and, on the other side, they condition a spatial allocation model of land use at a grid level. If local changes generate spillover effects across space that aggregate up to influence regional or even global outcomes, then an understanding of the reverse linkage (from local to global) is also necessary. This is particularly important for assessing the global implications of land-use competition, which may occur in many places locally, but in aggregate have impacts that accrue globally. Spatially explicit models that account for local conditions and spatial heterogeneity at microscales are needed to represent these local processes (Irwin and Wrenn 2013) and can be used to assess their cumulative effects on regional and global outcomes (Partridge and Rickman 2013). In addition to multiscale models, a range of new analytical approaches can contribute to improve the understanding of teleconnections and how they influence land-use competitions (see Eakin et al., this volume).

\section{Institutions for Managing Complexity under Uncertainty}

Institutions have always needed to address competition, but as competition increases, the stakes rise and institutional forms become more important. Equity is likely to be a growing issue on all scales, as competition for basic needs 
increases. Greater uncertainty from, for example, climate change also adds pressure on institutions. Fine tuning or, in some cases, redesigning institutions to be more efficient, more stable, and better able to respond to shocks will be increasingly important. Accelerated teleconnections could raise the efficiency of systems, but also make our systems more vulnerable, possibly requiring new institutional forms.

To respond to the needs of policy makers for advice on how to improve, replace, or supplement institutions, empirical analysis of existing institutional performance is needed. We already face competition and uncertainty, and thus can explore the responses of existing institutions to them; to a certain extent, what is changing is the intensity of the problem. However, simulation models are also needed; models that are simpler in geographic and other details than those discussed above, but which capture the essence of institutional forms and the pressures on them, so that we can simulate the likely behavior of potential future institutions. These are likely to be agent-based models that allow careful experimentation so as to lead to a new theoretical understanding of the robustness of institutions.

\section{Future Land-Use Competition}

Many other forms of land-use competition than those highlighted here are occurring, some of which are likely to become more important in the future, and new types are likely to emerge. For example, if demand for biofuels continues to grow and traditional food crops like maize, soybean, and oil palm are increasingly sold for energy, biofuel rather than food production could become the dominant competitor for conservation areas. Likewise, if an increasingly urban population in the developing world adopts diets with a higher share of organic food (similar to the Western world), land-use competition between organic (usually more extensive) agriculture and conventional agriculture may arise. Moreover, urban sprawl and vacation home construction could in some regions compete with conservation goals on a massive scale. Likewise, carbon sequestration and storage in forests via afforestation to mitigate climate change could compete with food or feed production. More attention needs to be given to the identification of emerging competitions and understanding the processes behind them.

\section{Conclusions}

In our increasingly urbanized and teleconnected world, land-system changes are characterized by different processes of land-use competition. Major drivers include rapid and massive increases in resource demand that result from economic and population growth, changes in diet toward more animal products, attempts to replace fossil fuels with land-based renewable energy, bioenergy, 
the growing demand for the conservation of nonprovisioning ecosystems, urbanization, and teleconnections. This competition is being played out in a global arena.

Three broad categories of land competition are (a) production versus production, (b) production versus provisioning services, and (c) built-up environment versus production or conservation. We have provided several examples of concrete competition processes (e.g., food vs. feed and food vs. bioenergy). Analysis of such concrete land-competition processes allows a better understanding of the trade-offs involved as well as the geographic location and socioeconomic/political contexts in which these competition processes occur. Various institutions at different scales are involved in defining the objectives for which land and resources are used, and they contribute to manage the competition between land uses. An analysis of long-term drivers and trajectories reveals that changes in energy systems are likely to have a strong influence on how these conflicts will shape the future development of the land system.

Knowledge gaps include the need for an improved analysis of future interdependencies of land and energy systems, the need to understand the importance of patterns in land systems (i.e., land architecture), and the need for multiscale models to assess local-global connections and impacts.

Many dimensions of land competition and its emerging dynamics and outcomes have yet to be adequately addressed by the land-change science community. A range of important research topics have been identified in this chapter. Some of these topics, however, appear to hold special significance, either in terms of their relatively recent emergence, and thus paucity of research attention given to them, or in regard to their looming implications for sustainability:

- Land for various forms of nonprovisioning ecosystem services and biodiversity maintenance, including carbon sequestration and environmental amenities, has become a major form of land use that is actively competing worldwide with other land uses; it is not a passive or residual category of land. These lands range from biosphere reserves and land acquired by NGOs or large corporations to smallholder forests preserved by PES or by local indigenous institutions.

- The growth of land required for bioenergy (solid, liquid, or gaseous) potentially looms large. Currently, land taken for this use may have a cascading effect on other agricultural lands and may directly or indirectly affect forests or other ecologically valuable land.

- Multifunction and heterogeneous land systems are being increasingly transformed to monofunctional and homogenous systems. The humanenvironment dimensions of this transformation require system-wide assessments. Analyses and planning at the landscape level might be increasingly important to minimize and balance the trade-offs that arise from land-use competitions as well as maximize the synergies across land uses. 
- The critical land uses and systems generating "high-cost-to-advert" damages need to be identified, as do the institutional failures associated with them.

- Land system assessments require methodological advances to consider trade-offs among different land uses and land covers, as well as to account for multiple, interacting human-environment dimensions and the spatial interactions among these dimensions.

Making research progress on these pressing issues of land competition and sustainability requires better data, data integration, and modeling to assess the trade-offs across the many, but interdependent, social and environmental scales that both influence and are impacted by land competition. 